\title{
Evaluation of phytochemical and superoxide dismutase activities of Enhalus acoroides (L.f.) Royle from coastal waters of North Sulawesi, Indonesia
}

\author{
Febry S. I. Menajang ${ }^{1,2}$, Mohammad Mahmudi ${ }^{3}$, Uun Yanuhar $^{3}$ and Endang Yuli Herawati ${ }^{3}$
}

1. Doctoral Program, Faculty of Fisheries and Marine Science, Brawijaya University, Malang 65145, East Java, Indonesia; 2. Department of Aquatic Resource Management, Faculty of Fisheries and Marine Science, Sam Ratulangi University, Manado, 95115, North Sulawesi, Indonesia; 3. Department of Aquatic Resource Management, Faculty of Fisheries and Marine Science, Brawijaya University, Malang 65145, East Java, Indonesia.

Corresponding author: Febry S. I. Menajang, e-mail: febrymenajang@unsrat.ac.id

Co-authors: MM: mudi@ub.ac.id, UY: doktoruun@ub.ac.id, EYH: herawati_ey@ub.ac.id

Received: 27-11-2019, Accepted: 26-02-2020, Published online: 13-04-2020

doi: www.doi.org/10.14202/vetworld.2020.676-680 How to cite this article: Menajang FSI, Mahmudi M, Yanuhar U, Herawati EY (2020) Evaluation of phytochemical and superoxide dismutase activities of Enhalus acoroides (L.f.) Royle from coastal waters of North Sulawesi, Indonesia, Veterinary World, 13(4): 676-680.

\begin{abstract}
Background and Aim: Seagrasses are an excellent and potential bioresource to discover new natural bioactive compounds such as antioxidants that have beneficial effects on health. Natural antioxidants have many functions in biological systems, primarily for defense against oxidation which produces free radicals in food, chemicals, and living systems. This study aimed to discover new natural antioxidant agents, Enhalus acoroides (L.f.) Royle was evaluated for phytochemical constituents and the antioxidant activity against superoxide dismutase (SOD) was assessed.
\end{abstract}

Materials and Methods: Sample specimens of E. acoroides (L.f.) Royle collected from two different areas, ManemboNembo, Bitung (SG-A) and Bahoi, Likupang Barat (SG-B) waters, were extracted with methanol and solutions were prepared in a concentration series.

Results: Extracts of the seagrass E. acoroides (L.f.) Royle cultivated in different areas have different phytochemical constituents and SOD activities. The secondary metabolites of phenols, flavonoids, and steroids contained in the ethyl acetic extracts of $E$. acoroides were linearly correlated with their antioxidant activity, whichexhibited an $\mathrm{IC}_{50}$ of $7 \mathrm{ppm}$.

Conclusion: E. acoroides (L.f.) Royle samples cultivated in the two areas contained different phytochemical constituent profiles, indicating an effect of environmental factors, and both can be used as potential natural sources of antioxidant compounds.

Keywords: Enhalus acoroides (L.f.) Royle, phytochemical, superoxide dismutase.

\section{Introduction}

Free radicals are highly reactive compounds produced in our body through daily metabolic processes [1]. Antioxidants in biological systems have many functions, including protection from oxidative damage and in major signaling pathways of the cell. The main action of antioxidants in cells is to prevent damage caused by the action of reactive oxygen species (ROS) [2]. Natural antioxidants have many functions in biological systems primarily for defense against oxidation, which produces free radicals in food, chemicals, and living systems [3]. Because of carcinogenicity, synthetic compounds have a deficiency in natural antioxidants. Natural antioxidants have an important role in the mechanism of antioxidant defense in biological systems and act as an

Copyright: Menajang, et al. Open Access. This article is distributed under the terms of the Creative Commons Attribution 4.0 International License (http://creativecommons.org/licenses/ by/4.0/), which permits unrestricted use, distribution, and reproduction in any medium, provided you give appropriate credit to the original author(s) and the source, provide a link to the Creative Commons license, and indicate if changes were made. The Creative Commons Public Domain Dedication waiver (http:// creativecommons.org/publicdomain/zero/1.0/) applies to the data made available in this article, unless otherwise stated. antidote to free radicals [4]. To prevent damage from free radicals, living organisms, including humans, have an immune system that can produce antioxidants naturally from the body, namely, endogenous antioxidants [5]. In addition, antioxidants can also be obtained from food intake, i.e. exogenous antioxidants. Thus, many natural antioxidants have been isolated from various natural resources such as vegetable oil, cereal crops, vegetables, spices, and herbs [6]. In sea plants, there are two good groups as sources of antioxidants, namely, seaweeds and seagrasses [5]. Seagrasses are a group of around 60 species of flowering plants growing in the sea and form the most extensive and productive coastal system in the world [7].

In traditional medicine, Enhalus acoroides (L.f.) Royle has been used for various repair purposes, for example, for the treatment of fever and skin diseases [8], muscle aches [9], wounds [10], stomach problems [11], drugs for stings from various types of rays [12], and as sedatives for babies [13]. E. acoroides (L.f.) Royle produces antimicrobial compounds that can act to reduce or control microbial growth and many studies describe antibacterial [14], antifungal [15], antiviral [16], anti-inflammatory [17], antidiabetic [18], and antioxidant [19] activities. Seagrasses, including E. acoroides 
(L.f.) Royle, are easily found in Indonesia; the species can be easily identified because it has distinct morphologies. E. acoroides (L.f.) Royle roots, stems, and leaves are larger than those of other seagrass species found in Indonesia [20]. Seagrasses are a functional group of flowering plants rooted in the world's coastal seas, known for their secondary metabolites [21]. Seagrasses comprise 49 species from 12 genera distributed throughout the world. E. acoroides (L.f.) Royle belongs to Enhalus, a monotypic marine genus in the family Hydrocharitaceae, which is widespread along the coast of the Indian Ocean and the tropical Pacific West [22].

E. acoroides (L.f.) Royle breed and develop several strategies to survive in an environment with a salt concentration of about $200 \mathrm{mM} \mathrm{NaCl}$ or more. When such plants grow in very high saline conditions, it is hypothesized that they can have rare and new activities, which are not reported in their terrestrial relatives [23]. Humans, especially coastal residents, usually consume E. acoroides (L.f.) Royle as food [24].

This study aimed to discover new natural antioxidant agents, Enhalus acoroides (L.f.) Royle was evaluated for phytochemical constituents and the antioxidant activity against superoxide dismutase (SOD) was assessed.

\section{Materials and Methods}

Ethical approval

Ethics approval was not required for this study.

\section{Chemicals and reagents}

The distillated organic solvents of $n$-hexane, ethyl acetic, and methanol were used for sample extraction. For the antioxidant assay, SOD reagents nitro blue tetrazolium (NBT), riboflavin, $\mathrm{N}, \mathrm{N}, \mathrm{N}$ ', N'tetramethyl ethylenediamine (TEMED), and PBS were purchased from Amresco. The thin-layer chromatography (TLC) spray reagent, 10\% sulfuric acid in ethanol, used in this study was purchased from Merck and Sigma-Aldrich. Kiesel G 60 silica gel resins and ODS columns of LiChroprep RP-18 (Merck, Darmstadt, Germany) were used for column chromatography. TLC analysis was performed using Kiesel gel $60 \mathrm{~F}_{254}$ and RP-18 $\mathrm{F}_{254 \mathrm{~S}}$ (Merck). Deuterated solvents were purchased from Merck Co., Ltd., and Sigma-Aldrich Co., Ltd. (St. Louis, MO, USA).

\section{Instruments}

Nuclear magnetic resonance (NMR) spectra were recorded on a $500 \mathrm{MHz}$ Fourier transform (FT)-NMR spectrometer (Varian ECA 500 JOEL, Japan). Infrared (IR) spectra were obtained using a PerkinElmer Spectrum One FT-IR spectrometer (Buckinghamshire, England). Mass spectra were obtained using an electrospray ionization mass spectrometry (ESI-MS) (ultra-performance liquid chromatography MS/MS TQD type, Waters). 2,2-diphenyl-1-picrylhydrazyl and SOD assays were measured on a Biochrom Ez Read 400 ELISA Reader.

\section{Plant material collection and determination}

The seagrass E. acoroides (L.f.) Royle was cultivated and collected in May 2016 from ManemboNembo, Bitung (SG-A) and Bahoi, Likupang Barat, Manado (SG-B), North Sulawesi, Indonesia. The specimen was deposited and identified at the Laboratory of Plant Taxonomy, Department of Biology, Faculty of Mathematics and Natural Sciences, Padjadjaran University, Bandung, Indonesia.

\section{Preparation of extract}

After collection, the fresh plants of E. acoroides (L.f.) Royle were washed well and cut into small-sized pieces. The samples were extracted with methanolfor 3 days and subsequently partitioned using water- $n$ hexane and water-ethyl acetate to yield concentrated extracts, as shown in Table-1. The obtained extract was filtered, concentrated in vacuum, and divided into a series of concentrations for phytochemical screening and SOD antioxidant activity assessment.

\section{Preliminary phytochemical screening}

Screening for secondary metabolites such as alkaloids, terpenoids, and flavonoids was performed using methanol, $n$-hexane, ethyl acetate, and water extracts of vegetables and fruits as described previously $[25,26]$.

\section{TLC analysis}

The chemical constituent profile of the extract and pure active compounds of the seagrass E. acoroides (L.f.) Royle cultivated in different areas was analyzed using a combination of TLC on Silica $60 \mathrm{G}_{\mathrm{F} 254}$ and ODS RP-18 plates eluted with a combination of organic solvent and $\mathrm{H}_{2} \mathrm{O}$. Chemical compounds on plates were identified and observed under ultraviolet (UV) lamps at 254 and $365 \mathrm{~nm}$ and through the reaction to the specific spraying reagent of $\mathrm{H}_{2} \mathrm{SO}_{4}$ in $10 \%$ EtOH $[25,26]$.

\section{SOD antioxidant activity assay}

The SOD-mimic activity of compound 1 was evaluated using an indirect method of riboflavin photoreduction as described previously [27]. The method involves the competitive reaction between the complex and reduced NBT for $\mathrm{O}_{2} \%$ - generated by riboflavin under illumination at room temperature $\left(25^{\circ} \mathrm{C}\right)$. The sample mixture $(240 \mu \mathrm{L})$ contained the complex (11 different concentrations), $6 \mu \mathrm{M}$ riboflavin, $0.8 \mu \mathrm{M}$ of $N, N, N$ ', $N$ '-tetramethylethylenediamine (TMEDA) in $0.016 \mathrm{M}$ phosphate buffer (pH 7.4), and $85 \mu \mathrm{M}$ NBT. The reaction was stopped by switching off the light after $15 \mathrm{~min}$ (four fluorescence tubes, Philips TLD $/ 20 \mathrm{~W}, 20 \mathrm{~cm}$ distance) and the absorbance of reduced NBT was measured at $\lambda 560 \mathrm{~nm}$ with

Table-1: Data of weight extracts of specimen.

\begin{tabular}{lcccc}
\hline Samples & \multicolumn{4}{c}{ Extracts weight (g) } \\
\cline { 2 - 5 } & MeOH & n-hexane & EtOAc & $\mathbf{H}_{\mathbf{2}} \mathbf{O}$ \\
\hline SG-A (4.13 kg) & 101.34 & 20.51 & 40.67 & 16.89 \\
SG-B (2.23 kg) & 98.25 & 15.34 & 38.88 & 20.67 \\
\hline
\end{tabular}


a Multiskan Go Thermo Fisher Scientific UV/visible double-beam spectrophotometer.

\section{Structural determination of active compound}

Antibacterial compound 1 obtained was then further analyzed using an ${ }^{1} \mathrm{H}-\mathrm{NMR}$ (JEOL 500 $\mathrm{MHz}$ ), ${ }^{13} \mathrm{C}$-NMR (JEOL $\left.125 \mathrm{MHz}\right),{ }^{1} \mathrm{H}-{ }^{1} \mathrm{H}$ COSY, and heteronuclear multiple-bond correlation (HMBC) spectrometer.

\section{Results}

Phytochemicals screening of the seagrass extracts

Phytochemical analysis for the presence of secondary metabolite constituents in the specimen indicated that flavonoid compounds were found in all the extracts. The methanol extract contained phenols, steroid, and tannin; the ethyl acetic extract contained phenols and steroid; whereas the water extract contained phenols and tannin, as shown in Table-2. In contrast, interestingly, no alkaloids were found in any of the extracts of both seagrass specimens.

\section{Antioxidant (SOD) activity}

The increased concentration in E. acoroides (L.f.) Royle extract could capture free radicals, especially in the ethyl acetic extracts. Increase in antioxidant activity from $E$. acoroides (L.f.) Royle extracts of methanol, $n$-hexane, ethyl acetic, and water was dependent on the concentration of each extract. The inhibition zone values of $E$. acoroides (L.f.) Royle (SG-A) extract in these solvents were $10,46,7$, and $33 \mathrm{ppm}$, respectively, which were better or more active than those of SG-B, as shown in Table-3.

\section{Isolation of antioxidant compound from the EtOAc of} E. acoroides (L.f.) Royle SG-A

The active antioxidant extract of the ethyl acetate fraction (E. acoroides (L.f.) Royle SG-A) was selected for further separation of active compounds. Ethyl acetate extract $(1.8451 \mathrm{~g})$ chromatographed on Silica G 60 eluted with $n$-hexane-ethyl acetate (5\% stepwise) resulted in 12 fractions. Purification of fraction 6 by chromatography on ODS RP-18 eluted with $\mathrm{H}_{2} \mathrm{O}-\mathrm{MeOH}$ ( $5 \%$ stepwise) resulted in 20 fractions. Further, purification of fractions 17 and 18 by chromatography on ODS RP-18 eluted with $\mathrm{H}_{2} \mathrm{O}-\mathrm{MeOH}$ (5\% stepwise) resulted in one active fraction of compound 1 .

\section{Structure determination of compound 1}

Compound 1 was isolated as a yellow solid, which was soluble in methanol. The ${ }^{13} \mathrm{C}-\mathrm{NMR}$ spectrum showed 14 carbon signals, including for one carbonyl carbon at $\delta_{\mathrm{C}} 173.9 \mathrm{ppm}$ and $13 s p^{3}$ carbons at $33.4,31.8,29.6,29.5,29.4,29.2,19.0,28.8,28.6$, $28.5,24.8,22.4$, and $13.5 \mathrm{ppm}$. Correlated to protons attached to carbons, the ${ }^{1} \mathrm{H}-\mathrm{NMR}$ spectrum indicated 13 methylene and one hydroxyl proton $\left(\delta_{\mathrm{H}} 2.9 \mathrm{ppm}\right)$. From the HMBC spectrum, the carboxylic group was attached at $\mathrm{C} 13$ by correlation peaks between hydroxyl protons to carbon $\mathrm{C}-13$ and another was attached to linear carbon. Based on the analysis of 1D and 2D-NMR spectra, the structure of compound 1 was suggested as myristic acid or tetradecanoic acid, as shown in Figure-1. Confirmation of the structure of 1 with reference to reported data indicated the synthetic compound as the same compound obtained from myristic acid as reported by Oria et al. [28]. Furthermore, to the best of our knowledge, the active compound 1 isolated from the seagrass $E$. acoroides (L.f.) Royle is reported for the $1^{\text {st }}$ time in this study.

\section{Discussion}

Recently, the need for research and development to identify a good source of marine plants that contain antioxidants has been recognized. Seagrass is one of the potential natural sources that are rich in antioxidants and the information on their bioactivity and active constituents are important aspects for improvement as new natural foods having benefits for humans.

Phytochemicals screening data presented in Table-2 give important information and show that both samples of $E$. acoroides (L.f.) Royle contain important secondary metabolites such as phenols, flavonoids, steroids, triterpenoids, saponins, and tannins, which have been reported to have anticancer, antibacterial, and antidiabetic bioactivities and act as antioxidant agents. Interestingly, alkaloid secondary metabolites were not found in both sample extracts of E. acoroides (L.f.) Royle. The distribution of secondary metabolites in both samples was different, which indicated that the accumulation or formation of these secondary metabolites in SG-A and SG-B seagrasses was affected by their environment. These preliminary

Table-2: Data of phytochemical specimen extracts.

\begin{tabular}{|c|c|c|c|c|c|c|c|c|c|}
\hline \multirow[t]{3}{*}{ Secondary metabolites } & \multirow[t]{3}{*}{ Test method } & \multicolumn{8}{|c|}{ Test result } \\
\hline & & \multicolumn{2}{|c|}{ МеОН } & \multicolumn{2}{|c|}{ n-hexane } & \multicolumn{2}{|c|}{ EtOAc } & \multicolumn{2}{|c|}{$\mathrm{H}_{2} \mathrm{O}$} \\
\hline & & $\mathbf{A}$ & B & A & B & $\mathbf{A}$ & B & $\mathbf{A}$ & B \\
\hline Phenolic & $\mathrm{FeCl}_{3} 5 \%$ & + & + & - & + & + & + & + & - \\
\hline \multirow[t]{3}{*}{ Flavonoid } & a. $\mathrm{HCl}+\mathrm{Mg}$ & - & + & - & + & - & - & - & + \\
\hline & b. $\mathrm{H}_{2} \mathrm{SO}_{4} 2 \mathrm{~N}$ & + & + & + & - & + & + & + & + \\
\hline & c. $\mathrm{NaOH} 10 \%$ & + & + & + & + & + & - & + & - \\
\hline Alkaloid & Dragendorff's & - & - & - & - & - & - & - & - \\
\hline Steroid & Liebermann-Burchard & + & + & - & - & + & + & - & - \\
\hline Triterpenoid & & - & + & - & - & - & + & - & - \\
\hline Saponin & $\mathrm{HCl}+\mathrm{H}_{2} \mathrm{O}$ & - & + & - & + & - & + & - & - \\
\hline Tannin & $\mathrm{FeCl}_{3} 1 \%$ & + & + & - & - & - & + & + & - \\
\hline
\end{tabular}


Table-3: Data superoxide dismutase activity of seagrass extracts.

\begin{tabular}{lcccc}
\hline \multirow{2}{*}{ Samples } & \multicolumn{4}{c}{ Inhibition Activity ( IC $_{\mathbf{5 0}}$ / ppm) } \\
\cline { 2 - 5 } & $\boldsymbol{n}$-hexane & EtOAC & $\mathbf{H}_{\mathbf{2}} \mathbf{0}$ & MeOH \\
\hline SG-A & 46 & 7 & 33 & 10 \\
SG-B & 55 & 10 & 55 & 24 \\
Quercetin & \multicolumn{5}{c}{5} & & \\
Catechin & \multicolumn{5}{c}{13} \\
\hline
\end{tabular}

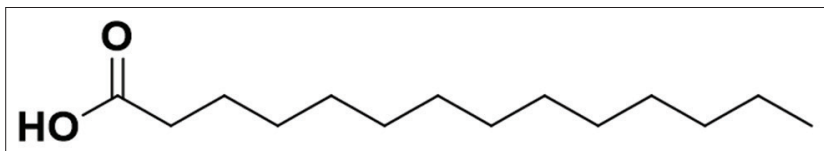

Figure-1: Structure of compound 1 (myristic acid or tetradecanoic acid).

data suggest the potential for the use of seagrass as a natural source of bioactive compounds.

To evaluate the antioxidant activity of seagrass, the extracts of SG-A and SG-B were assayed against SOD. Assay data showed that the ethyl acetate extract was the most active with an $\mathrm{IC}_{50}$ value of $7 \mathrm{ppm}$ when compared to quercetin and catechin as reference compounds that have $\mathrm{IC}_{50}$ values of 5 and $13 \mathrm{ppm}$, respectively. The phytochemical screening and SOD assay data indicated good correlations and suggested that the high SOD activity of the EtOAc extract was derived from the phenolic and flavonoid content in the extract. The secondary metabolites of phenols, flavonoids, and steroids contained in the ethyl acetic extracts were linearly correlated with their antioxidant activity. Therefore, the initial data are an important finding for further guidance in isolating their active constituents. The ethyl acetate extract had many aromatic compounds, such as phenols and flavonoids. Aromatic compounds are chemicals that contain conjugated planar ring systems that have delocalized $\pi$-electron clouds, such as benzene and toluene [28]. Phenol is the main antioxidant found in fruit with potential health benefits that include antioxidant, anti-inflammatory, antimicrobial, and anti-carcinogenic properties [29]. Flavonoids are a large group of plant polyphenols widely distributed in nature and contained in human food. Flavonoids have attracted attention because their antioxidant activity is stronger than that of Vitamins C and E. Steroid compounds show the highest activity in the generation of intracellular ROS [30,31].

SOD is the first detoxification enzyme and the most powerful antioxidant in cells. This is an important endogenous antioxidant enzyme that acts as a component of the first line of defense against ROS. Excessive SOD can produce free radicals from the reaction $\left(\mathrm{H}_{2} \mathrm{O}_{2}+\mathrm{e}^{-} \rightarrow * \mathrm{OH}\right)$. Therefore, antioxidants are needed to counteract SOD free radicals [32].

The study by Sureda et al. [33] showed that the antioxidant activity of the methanol extract of Posidonia oceanica had an $\mathrm{IC}_{50}$ of $7.67 \%$; these results show slight differences from those for E. acoroides (L.f.) Royle extract. The antioxidant activity of the extract of E. acoroides (L.f.) Royle. was much better than that reported by Box et al. [34] from the algae $L$. lallemandii using the SOD method yielding an $\mathrm{IC}_{50}$ value of $14.3 \mathrm{ppm}$ [34]. In contrast, compound 1 showed a SOD activity of $28 \mathrm{ppm}$. The SOD activity of compound 1 isolated from seagrass E. acoroides (L.f.) Royle is published, to the best of our knowledge, for the $1^{\text {st }}$ time in this report.

\section{Conclusion}

The seagrass E. acoroides (L.f.) Royle cultivated in two different areas showed differences in the biosynthesis of their secondary metabolites and their $\mathrm{IC}_{50}$ values for the SOD assay. These research data also suggest that the seagrass E. acoroides (L.f.) Royle has potential bioactive compounds as a source of natural antioxidants.

\section{Authors' Contributions}

FSIM designed the study and drafted the manuscript. MM collected the research data, UY analyzed the data. EYH reviewed the manuscript. All authors read and approved the final manuscript.

\section{Acknowledgments}

The researchers would like to express gratitude to Dikdik Kurnia, Ph.D (Department of Chemistry, Faculty of Mathematics and Natural Sciences, Universitas Padjadjaran, Bandung, Indonesia) for his expert advice throughout this research. This research received no specific grant from any funding agency in the public, commercial, or not-for-profit sectors.

\section{Competing Interests} interests.

The authors declare that they have no competing

\section{Publisher's Note}

Veterinary World remains neutral with regard to jurisdictional claims in published institutional affiliation.

\section{References}

1. Sarika, N.C. and Seenivasan, R. (2015) DPPH radical scavenging activity of selected seagrasses from South East Coast of India. Int. J. Adv. Res., 3(10): 950-956.

2. Kannan, R.R.R., Arumugam, R. and Anantharaman, P. (2010) In vitro antioxidant activities of ethanol extract from Enhalus acoroides (L.F) Royle. Asian Pac. J. Trop. Med., 12(1): 898-901.

3. Amudha, P., Vapita, V., Barathi, P.N., Jayalakshmi, M. and Mohanasundaram, S. (2017) Phytochemical analysis and in vitro antioxidant screening of seagrass Enhalus acoroides. Int. J. Res. Pharm. Sci., 8(2): 251-258.

4. Jeyapragrash, D., Subhashini, P., Abirami, K. and Thangaradjou, T. (2016) Evaluation of in-vitro antioxidant activity of seagrass: Signal for potential alternate source. Free Rad. Antiox., 6(1): 77-89.

5. Santoso, J., Anwariyah, S., Rumiyanti, R.O., Putri, A.P., Ukhty, N. and Stark, Y.Y. (2012) Phenol content, antioxidant activity and fibers profile of four tropical seagrasses 
from Indonesia. J. Coast. Dev., 15(2): 189-196.

6. Kannan, R.R.R., Arumugam, R., Meenakshi, S. and Anantharaman, P. (2010) Thin layer chromatography analysis of antioxidant constituents from seagrass of Gulf of Mannar. Int. J. Chem. Tech. Res., 2(3): 1526-1530.

7. Rengasamy, R.R., Rajasekaran, A., Micheline, G.D. and Perumal, A. (2012) Antioxidant activity of seagrass of the Mandapam Coast, India. Pharm. Biol., 50(2): 182-187.

8. Sangetha, J. and Asokan, S. (2015) Antibacterial activity of different seagrass extracts against some human eye pathogens. World J. Pharm. Sci., 4(12): 677-683.

9. Gumguje, E.N.M., Bukhari, D.A. and Hajar, A.S. (2018) Evaluation of antioxidant and antibacterial properties of Halophila stipulacea leaves extracts obtained from (Alwajh) North of Yanbu city. Aust. J. Basic. Appl. Sci., 12(6): 8-11.

10. Vichkovitten, T., Interachart, A., Khaodon, K. and Rermdumri S. (2016) Transplantation of tropical seagrass Enhalus acoroides (L.). GMSARN Int. J., 10(1): 113-120.

11. Klangprapun, S., Buranrat, B., Chaichompoo, W. and Nualkaew, S. (2018) Pharmacognostical and physicochemical studies of Enhalus acoroides (L.F.) Royle (Rhizome). Pharmacogn. J., 10(6): 113-120.

12. Bharathi, N., Amudha, P. and Vanitha, V. (2016) Seagrassnovel marine nutraceuticals. Int. J. Pharm. Biosci., 7(4): 86-94.

13. Notarte, K.I., Yaguchi, T., Suganuma, K. and Cruz, T.E. (2018) Antibacterial, cytotoxic and trypanocidal activities of marine-derived fungi isolated from Philippine macroalgae and seagrasses. Acta Bot. Croat., 77(2): 141-151.

14. Jebasingh, S.E., Lakshmikandan, M., Sivaraman, K. and Uthiralingam, M. (2015) Assessment of antibacterial, antifungal property and purification of bioactive compounds from seagrass, Thalassia hemprichii. Proc. Natl. Acad. Sci. India Sec. B Biol. Sci., 15(2): 1-6.

15. Prakash, S., Ramasubburayan, R., Ramkumar, V.S., Kannapiran, E., Palavesan, A. and Immanuel, G. (2016) In vitro scientific evaluation on antimicrobial, antioxidant, cytotoxic properties and phytochemical constituents of traditional coastal medicinal plants. Biomed. Pharmacother. 83: 648-657

16. Widiyanto, A., Anwar, E. and Nurhayati, T. (2018) In vitro assay of alpha-glucosidase inhibitor activities of three seagrasses from Banten Bay, Indonesia. Pharmacogn. J., 10(5): 907-910.

17. Akah, P.A., Uzodinma, S.U. and Okolo, C.E. (2011) Antidiabetic activity of aqueous and methanol extract and fractions of Gongronema latifolium (Asclepidaceae) leaves in alloxan diabetic rats. J. Appl. Pharm. Sci., 1(9): 99-102.

18. Nindatu, M., Noya, F., Seimahumaira, T., Kaya, E., Wakano, D. and Leasa, M. (2016) Potential of Lamun (Enhalus acoroides) seeds from West Seram Coastal area as natural antioxidant. Res. J. Pharm. Biol. Chem. Sci., 7(2): 66-71.

19. Dewi, C.S.U., Kasitowati, K.D. and Siagian, J.A. (2018) Phytochemical compounds of Enhalus acoroides from Wanci Island (Wakatobi) and Talago Island (Madura) Indonesia. IOP Conf. Ser. Earth Environ. Sci., 137(1): 1-6.

20. Subhashini, P., Dilipan, E., Thangaradjou, T. and Papenbrock, J. (2013) Bioactive natural products from marine angiosperms: Abundance and functions. Nat. Prod. Biosprospect., 3(2013): 129-136.

21. Qi, S.H., Zhang S., Qian, P.Y. and Wang, B.G. (2008)
Antifeedant, antibacterial, antiviral compounds from the South China sea seagrass Enhalus acoroides. Bot. Mar., 51(5): 441-447.

22. Vincenti, L.D., Glasenapp, Y., Catto, C., Villa, F., Cappitelli, F. and Papenbrock, J. (2018) Hindering the formaton and promoting the dispersion of medical biofilm: Non-Lrthal effect of seagrass extracts. Complement. Alter. Med., 18(168): 1-17.

23. Kannan, R.R.R., Arumugam, R., Iyapparaj, P., Thangaradjou, T. and Anantharaman, P. (2013) In vitro antibacterial, cytotoxicity and haemolytic activities and phytochemical analysis of seagrass from the Gulf of Mannar, South India. Food Chem., 136(3-4): 484-1486.

24. Harbone, J.B. (1973) Phytochemical Methods: A Guide to Modern Technique of Plant Analysis. $2^{\text {nd }}$ ed. New York: Chapman and Hall.

25. Kokate, C.K.(2005)A Textbook of Practical Pharmacognosy. Vallabh Prakashan, New Delhi. p105-111.

26. Deawati, Y., Onggo, D., Mulyani, I., Hastiawan, I., Kurnia, D., Lonnecke, P., Schmorl, S., Kersting, B. and Hawkins, E.H. (2018) Synthesis, crystal structures, and superoxide dismutase activity of two new multinuclear manganese (III)-Salen-4,4'-bipyridine complexes. Inorganica Chim. Acta, 482(1): 353-357.

27. Evergentis, E. and Haroutounian, S.A. (2014) Exploitation of Apiaceae family plants as a valuable renewable source of essential oils containing crops for the production of fine chemicals. Ind. Crop. Prod., 54(2014): 70-77.

28. Oria, A.B., Gutierrez, G.R., Prior, A.F., Vioque, B. and Bolanos, J.F. (2019) Strawberry dietary fiber functionalized with phenolic antioxidants from olives. Interactions between polysaccharides and phenolic compounds. Food Chem., 280(2019): 310-320.

29. Yang, S.L., Zhao, L.J., Chi, S.M., Du, J.J., Ruan, Q., Xiao, P.L. and Zao, Y. (2019) Inclusion complexes of flavonoids with propylene diamine modified $\beta$-cyclodextrin: Preparation, characterization and antioxidant. J. Mol. Struct., 1183(2019): 118-125.

30. Sadaba, L.M., Fern, P., Fandezrobredo, J.A., Rodríguez, A. and Garcíalayana (2008) Antioxidant effects of Vitamins C and $\mathrm{E}$, multivitamin-mineral complex and flavonoids in a model of retinal oxidative stress: The apoe-deficient mouse. Exp. Eye Res., 86(3): 470-479.

31. Siddiqui, M.A., Ali, Z., Chittiboyina, A.G. and Khan, I.A. (2018) Hepatoprotective effect of steroidal glycosides from Dioscorea villosa on hydrogen peroxide-induced hepatotoxicity in HepG2 cells. Front. Pharmacol., 9(797): 1-12.

32. Ighodaro, O.M. and Akinloye, O.A. (2018) First line defense antioxidants-superoxide dismutase (SOD), catalase (CAT) and glutathione peroxidase (GPX): Their fundamental role in the entire antioxidant defence grid. Alex. J. Med., 54(4): 287-293.

33. Sureda, A., Box, A., Terrados J., Deudero, S. and Pons, A. (2008) Antioxidant response of the seagrass Posidonia oceanica when epiphytized by the invasive macroalgae Lophocladia lallemandii, Mar. Environ. Res., 66(3): 539-363.

34. Box, A., Sureda, A., Terrados, J., Pons, A. and Deudero, S. (2008) Antioxidant response and caulerpenyne production of the alien Caulerpa taxifolia (Vahl) epiphytized by the invasive algae Lophocladia lallemandii (Montagne). J. Exp. Mar. Biol. Ecol., 364(1): 24-28.

\section{$* * * * * * * *$}

